\section{Power and University}

\section{Presidents}

\section{AMANDA GOOdALL}

Amanda Goodall is the Leverhulme Fellow, Warwick Business School, University of Warwick, UK. E-mail: Amanda.Goodall@wbs.ac.uk. This article relates to the author's book Socrates in the Boardroom: Why Research Universities Should be Led by Top Scholars, published by Princeton University Press.

The question of who should lead research universities has 1 been the focus of my work: should they be individuals who are essentially good managers, or are good scholars more desirable? In several IHE articles (in 2006 and 2007) I have stated, using statistical evidence, that as presidents top scholars improve the performance of research universities. Drawing from interviews with university leaders, I have raised four possible explanations for the empirical patterns. First, a president (vice chancellor, rector, principal) who is a distinguished scholar will essentially understand the core business of a university-that of research and teaching. The scholar-leaders will likely demand higher academic standards, and their appointment may also signal a university's priorities. Finally, they will have greater credibility among their academic peers.

\section{Presidents and University Strategy}

University presidents in the United States and United Kingdom were asked how much power each leader had in order to undertake certain tasks-for example, to design university strategy or hire top-team members. A total of i9 presidents were interviewed from the University of Pennsylvania, Harvard, Rockefeller University, Cornell, Oxford, London School of Economics and Political Science, Imperial College London, University of Manchester, and University of Southampton, among others.

In response to the question "whose role do you believe it is to write or construct the strategy for the university?" the degree of congruence was striking. With little or no hesitation, most of the leaders stated that it was the responsibility of the president or vice chancellor to set the direction of a university. The general feeling was that the president is the only person who can ask "Where are we going? What is our strategy?" Debates emerge, it was suggested, out of the top team, but the goal to finally determine an area of strategy remained with the head. Common among interviewees was the belief that if decision making is devolved too far down, leaders lose control, particularly regarding the academic direction.

Committees tend to have greater authority in European universities than those in the United States. However, as was evident from the interviews, UK vice chancellors are beginning to take away certain rights. The British heads stressed the leader's responsibility as differentiated from that of committees, argu- ing that it is the vice chancellor's role to form university strategy and then to get it approved, not the job of any committee.

A number of authors have argued that presidents need power if they are to successfully lead a university. Similarly, an institution that has too much "democracy" can become impotent. The decline of many European universities is attributed partially to their diffused decision-making processes-specifically, decision making by elected committees. Political scientists may refer to "tyranny of the majority." The form of consensus decision making that can exist in European universities protects the status quo and curtails the actions of leaders, thereby reducing the likelihood of change. In fact, some scholars have suggested that university presidents with possibly the most direct powers reside at some of the best schools in the world-for example, Ivy League institutions, Stanford, and California Institute of Technology. Seemingly, leaders are appointed to make decisions, direct the institution, and take the fall when things do not work out. This explains why they tend to receive the highest salary in their organizations. If governance mechanisms are functioning properly, powerful heads benefit universities

The scholar-leaders will likely demand higher academic standards, and their appointment may also signal a university's priorities.

\section{Selecting the Top-Management Team}

Another of the powers bestowed on university heads concerns the right to hire top-team members. These powers do exist for US presidents. There are a number of tiers of leadership in research universities. Below presidents are provosts, pro-vice chancellors and other deputy heads, senior administrative staff, and leaders of key strategic units-such as deans of schools or faculties. For a leader to execute strategies and extend his or her influence, it matters who is selected as provosts and pro-vice chancellors. It is normal for university presidents at American institutions to choose top-team members and make other important hires. But this practice is less established in the United Kingdom and even rarer in Europe.

Almost all of the I2 UK vice chancellors interviewed complained that they first needed to change or adapt the selection process, before hiring their own choice of top-team members. For some of these leaders this procedure was slow and involved a great deal of negotiation. One UK head protested that his actions had been blocked by incumbent pro-vice chancellors for two years, until their terms were completed. At his institution pro-vice chancellors were appointed by the senate, which had 200 members. This style of selection was common in the United Kingdom, but many of the interviewed leaders had started to flex their muscles. Some UK heads negotiated the power to hire top-team members as part of their contract. This was true in the case of an experienced leader who was 
asked to take over the reins of a weak and struggling university and introduced a new pro-vice chancellor, chief operating officer, and registrar, among others. One leader threatened to resign unless powers to select top-team members were transferred exclusively to the vice chancellor.

Collegiality does not necessarily mean that everyone makes decisions. This assertiveness by British heads is quite recent. Thus, at UK research universities, power to select top management teams is slowly following the US policy. In the United Kingdom, it is more common for heads of new universities (those established from polytechnics after I992) to have direct powers to hire top-team members.

The traditional and largely continuing European approach involves appointment through a process of faculty elections. This practice has been criticized because, again, it substantially weakens presidential powers, inhibits organizational change, and favors the status quo. One former and very experienced US dean said he was strongly opposed to faculty making the selection of provosts or presidents, and he went on to say, "I am against the notion of democracy." This is noteworthy because many academics construe universities to be collegial and therefore nonhierarchical, with democratic decision-making structures. This former US dean argued that universities are at least as hierarchical as the military, and our obsessive labeling would imply this is the case ("Professor Dr Dr" is not an uncommon title in Germany).

Leaders do need power. The executive powers given to university presidents in the United States extend far beyond those conferred on European rectors, although vice chancellors in the United Kingdom are becoming more assertive. The world's outstanding research universities are located in the United States. These top institutions outperform their European counterparts. Presidents having adequate clout in meritocratic organizations may explain some of this difference.

\section{A New Direction for Private Higher Education in India}

\section{Pawan Agarwal}

Pawan Agarwal is a senior civil servant in the Government of West Bengal, India and author of Indian Higher Education: Envisioning the Future (Sage, 2009). The views expressed here are personal. E-mail: apawano8@gmail.com.

I $n$ India private higher education accounts for more than a 1 third of overall enrollment and about four-fifths of enrollment in professional higher education. Although the country has a long history of institutions entirely funded through private initiatives, frantic growth of private institutions is a recent phenomenon. Currently, the established private institutions are consolidating their positions and gain scale by setting up new campuses, establishing new programs, and expanding into new geographies. As a result, chains of private institutions are emerging.

In India private higher education accounts for more than a third of overall enrollment and about fourfifths of enrollment in professional higher education.

While earlier a few trusts and philanthropic societies with broad representation of a community or a religious group used to set up such institutions, now most of such chains are family owned. Rather than being on the fringes, these new establishments are in mainstream higher education and distinct from chains of training centers built for instance by the National Institute of Information Technologies that achieved scale in the information technology training segment through its innovative model of franchising. Most of the chains had modest beginnings (with a few students graduating from the school to the higher education sector) and grew over time. And now all of them are onto major expansion spree.

\section{EARLIER INITIATIVES}

The Birla Institute of Technology and Science, Pilani is one of the oldest and perhaps the most prestigious of these chains and has retained its leadership through differentiated programs and strong industry linkages. It started in the early Igoos as a small school and blossomed into a set of colleges for a wide range of subjects ranging from humanities to engineering until ig 64 , when these colleges were amalgamated into a private university. By setting up campuses at Goa and Hyderabad in India and at Dubai abroad, the Birla Institute is now a multicampus university with about 9,००० students and I9,००० students enrolled in off-campus work-integrated programs.

The Manipal Education Group, with Manipal University as its flagship, is a leading player in professional education and distance learning in the country today. The group started with a medical college in I953 and now has 24 colleges with an enrollment of over 80,000 , in a range of subjects at all levelsmaking Manipal, a nondescript small town on the south coast, a major higher education hub. From its initial narrow focus on engineering and medical programs, it now offers programs in humanities and social sciences. The group was early to recognize the global opportunity and effectively leveraged its brand equity and experience for international expansion. It is spending US\$9o million to upgrade its Manipal facilities and setting up four campuses, investing about US\$25 to 30 million on each campus in India. To consolidate its overseas presence in Nepal, Malaysia, and Dubai, the group acquired the entire 